http://revped.ise.ro

\title{
INTERPROFESSIONAL COLLABORATION SKILLS TRAINING FOR SOCIAL AND EDUCATION FIELDS - A MODULE PROPOSAL
}

FORMAREA ABILITĂȚILOR DE COLABORARE INTERPROFESIONALĂ ÎN DOMENIILE SOCIAL ȘI EDUCAȚIONAL - PROPUNEREA UNUI MODUL

\section{Mirela ALEXANDRU}

\author{
Journal of Pedagogy, 2018 (1), 65 - 75 \\ https://doi.org/10.26755/RevPed/2018.1/65
}

The online version of this article can be found at: http://revped.ise.ro/category/2018-en/

\section{(c) (1) (2) (2) \\ BY NC SA}

This work is licensed under the Creative Commons Attribution-NonCommercial-ShareAlike 4.0 International License. 94042, USA.

Published by:

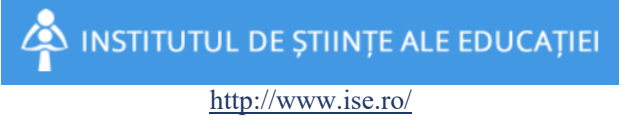

http://www.ise.ro/

Further information about Revista de Pedagogie - Journal of Pedagogy can be found at:

Editorial Policy: http://revped.ise.ro/editorial-policy/

Author Guidelines: http://revped.ise.ro/the-writer-guide-2/ 


\title{
INTERPROFESSIONAL COLLABORATION SKILLS TRAINING FOR SOCIAL AND EDUCATION FIELDS - A MODULE PROPOSAL
}

\author{
Mirela Alexandru* \\ Alumni VIA University College, \\ Holstebro, Denmark \\ alexandru.mirela.elena@gmail.com
}

\begin{abstract}
The need for interprofessional collaboration may be condensed in Reid Hoffman's words "No matter how brilliant your mind or strategy is, if you're playing a solo game, you'll always lose out to a team". In the current social context, there is a strong need for the development of interprofessional collaboration skills, given the increasingly complex problems for which employees need to find solutions. Important steps have been taken at world level to develop interprofessional skills to meet demands by setting up interprofessional work organizations and implementing skills development programs in this direction. Medicines and IT domains are the most advanced in facilitating interprofessional skills development contexts, while the educational and social domains are still in their infancy, being more advanced in some countries. In Romania the interprofessional education is still pioneering, in order to support the process of its development in our country, in this article we propose an interprofessional skills training model for educational and social fields tailored to the training practice at VIA University College, Holstebro, Denmark.
\end{abstract}

Keywords: higher education, interprofessional collaboration, interprofessional education, training.

\section{Rezumat}

Nevoia de colaborare interprofesională poate fi sintetizată în afirma ia lui Reid

* Alumni VIA University College, Holstebro, Denmark. 
Hoffman: „Nu contează cât de inteligent eşti sau cât de bună este strategia ta, dacă lucrezi singur, vei pierde întotdeauna în fa a unei echipe". În contextul social actual există o nevoie pregnantă de dezvoltare a competen elor de colaborare interprofesională, date fiind problemele din ce în ce mai complexe cu care se confruntă angaja ii pentru a răspunde solicitărilor. Domeniile medicale şi IT sunt cele mai avansate în privina facilitării de contexte de dezvoltare a competen elor interprofesionale, pe când domeniul educa ional şi cel social sunt în faza de început. În România, educa ia interprofesională este în faza de pionierat, pentru a facilita dezvoltarea acestei practici, propunem în acest articol un model de dezvoltare a competen elor de colaborare interprofesională pentru domeniile educa ional şi social adaptat din practica de formare a Universită ii VIA College, Holstebro din Danemarca.

Cuvinte-cheie: colaborare interprofesională, educa ie interprofesională, formare, invă ământ superior.

\section{Interprofessional collaboration - theoretical references}

Thousands of years ago, nature has "installed" in the brain of Homo sapiens a "hardware" called neocortex that has incorporated into our "central system" the elements of grammar and syntax. Thus, a long process of language development, communication, relationship and cooperation between people has begun. With this "tool" at hand, people have won a new "weapon" in the struggle for survival, namely the ability to communicate, to cooperate; since then, the greatest achievements of mankind have been gained in teams.

Today, when the interaction between people has been developed and we are being guided not only by the elementary goal of survival, it is important to maintain those mechanisms of cooperation and collaboration acquired throughout history in order to facilitate the development of an efficient a constant developing society.

Given that today we are largely defined in relation to our profession, it is necessary to use those mechanisms of cooperation and communication in the professional environment, which leads to efficient and even interprofessional teams. In recent years, the idea of interprofessional collaboration has been approached, focusing on the benefits it generates (EMS, 2017). 
World Health Organization (1988) defines interprofessional collaboration as a collaborative practice that occurs when multiple workers from different professional backgrounds provide comprehensive services by working with beneficiaries and communities to deliver the highest quality of services across settings.

Interprofessional work is gaining momentum around the world through interprofessional education, as members of various professions "learn, with, from and about each other to improve collaboration and the quality of care" (Barr et al., 2005, p. 31). Practice of interprofessional work is transferred from medical field and was endorsed by the World Health Organization in 1988 arguing that interprofessional collaboration can:

- develop the ability to share knowledge and skills collaboratively;

- enable students to become competent in teamwork;

- decompartmentalize curricula;

- integrate new skills and areas of knowledge;

- ease interprofessional communication;

- generate new roles;

- promote interprofessional research;

- improve understanding and cooperation between educational and research institutions;

- permit collective consideration of resource allocation according to need;

- ensure consistency in curriculum design (WHO, 1988, p. 16 - 17).

Recent research has shown that interprofessional collaboration benefits both beneficiaries in terms of innovative solutions for their needs, as well as the members of interprofessional team, facilitating the overcoming of communication barriers, promoting a team mentality and empowering its members (ENS, 2018).

Interprofessional collaboration has been a practice developed especially in fields as medical, research or technology, to facilitate innovative solutions in treating diseases or to support technological development (Green \& Johnson, 2015). Given the success of these areas in recent years, the transfer to education or social fields was attempted. 


\section{Interprofessional collaboration in the educational and the social fields}

The development of interprofessional collaboration skills is a relatively new approach in the educational and the social fields and this ,,is about learning together to work together, being aware of one's own learning style and exploring one's own understanding and experience of working in groups" (Drynan, 2013).

In the field of education and social support, for which VIA University College trains professionals, interprofessional work is carried out especially at the intersection of education, health and care professional areas. However, in different contexts, in order to facilitate a valuable educational and social context for the beneficiaries, this requires collaboration with other professions.

In order to provide quality services adapted to the increasingly complex needs of individuals and implicitly those of the society, the educational field can apply a more flexible way of action, in terms of a multi-perspective approach for facilitating learning and development contexts.

Given the dynamics of the labour market, for which is anticipated a very important change in terms of skills required over the next 5, 10 years (World Economic Forum, 2015), and the impact of educational and social services at both individual and community level, there is an actual need of interprofessional work at the level of educational and social services. There is a need to develop interprofessional skills in order to prepare the new generations to face the complex and ever-changing reality.

In some European countries as well as in Denmark, interprofessional work is a reality in many contexts, especially in the medical field, but a lot of good examples could also be found in the social and the educational fields. Denmark has a long history of interprofessional collaboration in the social and educational sphere; this has been enshrined in law, mostly in order to prevent the exclusion of people with social, physical or other disabilities and to improve the efficiency of services (Nielsen, Hamming 2008). 
Worldwide and European centres have been established to promote and support interprofessional collaboration, which also facilitates training programs in this direction, of which we mention CAIPE (Center for the Advancement of Interprofessional Education), IPEC (Interprofessional Education Collaborative) and InterEd (International Association for Interprofessional Education and Collaborative Practice.

\section{Interprofessional Education}

The genesis of interprofessional education is attributed to an expert group of Geneva in 1973, since then, many efforts have been made to conceptualize and implement interprofessional education (WHO, 1988).

It is defined as the context in which students of different specializations learn together, and from each other, during their initial training programs to develop their collaborative skills and the abilities to identify solutions from multiple perspectives (CAIPE, 1997).

IPE is a pedagogical approach, which, according to research in the medical field, has been shown to be very effective in developing participants' abilities to collaborate in identifying appropriate solutions in the perspective of a beneficiary-centreed approach (Barwell, Arnold, \& Berry, 2013).

As for the concept of interprofessional cooperation, this can be translated into competences as follows:

- knowledge of the specifics of one's own profession;

- communication techniques;

- communication abilities;

- active listening, collaboration;

- cooperation;

- ability to look from another perspective;

- adaptability;

- respect;

- ability to build relations;

- interprofessional conflict resolution capacity. 
In addition to these, other abilities, knowledge or attitudes can be added, depending on the context in which the students work (CIHC, 2010 p. 9).

Another approach to interprofessional competencies is structured in four dimensions in a Report of Interprofessional Education Collaborative (2016, p. 1), namely:

- Values/ethics - work with individuals of other professions to maintain a climate of mutual respect and shared values;

- Role/responsibilities - use the knowledge of one's own role and those of other professions to appropriately assess and address needs of beneficiaries;

- Interprofessional communication - communicate with beneficiaries and professionals in a responsive and responsible manner that supports the team objectives;

- Team \& Teamwork - apply relationship-building values and the principles of team dynamics to perform effectively in different team roles.

Dealing with the need and understanding the benefits of interprofessional education, worldwide and European universities has structured for initial training, and also for continuing training institutions, interprofessional skills development training modules, focusing on a transdisciplinary, multiperspective approach and on the ability to cooperate and work in teams.

In the education and the social fields, interprofessional skills development programs were implemented in the University of Southampton, University of Sydney, University of Melbourne (Pockett, 2010), VIA University Holstebro, Arhus and in other many universities focusing on communication and negotiation skills in interprofessional contexts.

Based on the information from the program developed in the universities mentioned above and on the observations of the implementation the interprofessional module at VIA University College Denmark we developed a training structure which can be implemented in the Romanian context. 


\section{Interprofessional work and education in Romania}

In Romania, the interprofessional collaboration is at the beginning and the practice and the literature in this direction is poor, especially in the educational and social field, but there is interest in this direction, in the process of taking over and implementing the interprofessional education practices, Romania took part in the debates on this issue within the web-based discussion conducted by Word Health Organization in 2010 (Barr, 2015).

In the legal, medical and agricultural fields there are manifestations of the interprofessional collaboration, materialized through associations and training programs such as Building Health Bucharest International Forum, the National Interprofessional Vineyards Organization or the Prodcom Vegetable-Fruit National Interprofessional Organization.

From the educational point of view, interprofessional competence training is poorly represented in the academic environment, specific to the educational and social fields, but it is a work in progress, as during academic year 2015 - 2016 the University of Bucharest, Faculty of Psychology and Educational Sciences has implemented a module for the development of interprofessional collaboration skills, using mainly working meetings between in training pedagogues and various other professions, this being one of the few attempts to develop this kind of skills in Romanian academic environment. This shows that there is a need to develop such competences and we are already trying to implement such training programs, even in pioneering phases.

Based on this precedent, analysing the global practices and adapting the Danish model, we will continue to present the proposal for a training structure that aims to develop interprofessional cooperation skills. We justify the development of such a program, given the developmental attempts in this direction in the Romanian context, and the benefits of interprofessional work presented by numerous researches in the field (EMS, 2017).

For the training program, we propose a modular structure that can easily be integrated into the students' schedule. It runs for 8 weeks and includes a training session focused on theoretical approaches, training sessions focused on practical approaches, and experiential sessions. 


\begin{tabular}{|c|c|}
\hline \multicolumn{2}{|c|}{ Structure of the training module } \\
\hline Module title & Interprofessional collaboration \\
\hline $\begin{array}{l}\text { Main objective of the } \\
\text { module }\end{array}$ & $\begin{array}{l}\text { Develop interprofessional collaboration skills through the } \\
\text { facility of experiential contexts. }\end{array}$ \\
\hline Beneficiaries & $\begin{array}{l}\text { Trainees from at least two specializations / professions that } \\
\text { require collaboration in the labour market. } \\
\text { In educational and social fields can be: pedagogues, teachers, } \\
\text { psychologists, social assistants, etc. }\end{array}$ \\
\hline Content of the module & $\begin{array}{l}\checkmark \text { General knowledge about the implications of } \\
\text { interprofessional collaboration in the educational and } \\
\text { social field; } \\
\checkmark \text { Theoretical and practical models focusing on } \\
\text { understanding the dimensions of interprofessional } \\
\text { interaction in professional activity for promoting of } \\
\text { integrated solutions across professions and sectors in order } \\
\text { to create change and value for relevant target groups; } \\
\checkmark \quad \text { Ethical and quality standards in beneficiary-centreed } \\
\text { services; } \\
\text { Methods and strategies to streamline communication and } \\
\text { facilitate productive collaboration; } \\
\checkmark \text { Values and roles in team, teamwork, process management, } \\
\text { feedback strategies, conflict and crisis management. }\end{array}$ \\
\hline $\begin{array}{l}\text { Learning objectives of } \\
\text { the module }\end{array}$ & $\begin{array}{l}\checkmark \text { Developing the capacity to understand and apply the } \\
\text { principles of interprofessional collaboration; } \\
\checkmark \quad \text { Developing the capacity to explain and reflect on their } \\
\text { own academic competence and professional identity in } \\
\text { relation to other professional in order to contribute to the } \\
\text { delivery of innovative solutions; } \\
\checkmark \text { Facilitating the understanding and application of ethical } \\
\text { and quality standards; } \\
\checkmark \text { Developing effective communication skills, teamwork, } \\
\text { conflict management and crisis management, process } \\
\text { management, and delivering constructive feedback. }\end{array}$ \\
\hline $\begin{array}{l}\text { Evaluation of the } \\
\text { module }\end{array}$ & $\begin{array}{l}\text { The evaluation will consist of producing and presenting an } \\
\text { intervention program for a specific case (example: a child at } \\
\text { risk of abandonment with a sensitive family situation and } \\
\text { competences below the age) in interprofessional teams. The } \\
\text { project will be presented to teachers and colleagues and will be } \\
\text { evaluated both by colleagues and by the teacher on a certain } \\
\text { evaluation grid, followed by a team reflection session and self- } \\
\text { evaluation. }\end{array}$ \\
\hline
\end{tabular}




\begin{tabular}{|c|c|}
\hline \multicolumn{2}{|c|}{ Process of the training } \\
\hline \multicolumn{2}{|c|}{$\begin{array}{l}\text { Students of the specializations will be divided into groups of } 20 \text {, with approximately equal } \\
\text { number of students from all the specializations involved. } \\
\text { In these groups of } 20 \text {, all training sessions will be carried out. After the training sessions, } \\
\text { the students form teams of } 5-6 \text { different specialists and are offered a case. Over the next } 3 \\
\text { weeks, they are working on a project to improve the situation of the subject / subjects for } \\
\text { which they will create a presentation and a poster. } \\
\text { In the final stage, after evaluation, the posters of the intervention programs will be } \\
\text { exhibited in the faculties. }\end{array}$} \\
\hline \multicolumn{2}{|c|}{ Agenda } \\
\hline Week 1 & $\begin{array}{l}\text { Parallel training sessions } \\
\text { 1. Interprofessional work and its implication } \\
\text { 2. Theoretical and practical models of interprofessional } \\
\text { collaboration in the educational and the social fields }\end{array}$ \\
\hline Week 2 & $\begin{array}{l}\text { Parallel training sessions } \\
\begin{array}{l}\text { 1. } \\
\text { Ethical and quality standards in beneficiary-centreed } \\
\text { services } \\
\text { 2. } \quad \text { Communication in interprofessional contexts }\end{array}\end{array}$ \\
\hline Week 3 & $\begin{array}{l}\text { Parallel training sessions } \\
\text { 1. Roles, values and process in team work } \\
\text { 2. } \text { Feedback }\end{array}$ \\
\hline Week 4 & $\begin{array}{l}\text { Parallel training sessions } \\
\text { 1. Conflict and crisis management } \\
\text { 2. Team working preparation }\end{array}$ \\
\hline Week 5 & $\begin{array}{l}\text { Working meetings } \\
* \text { Students meet in faculties to work and to be coordinated by teachers. }\end{array}$ \\
\hline Week 6 & Working meetings \\
\hline Week 7 & Working meetings \\
\hline Week 8 & $\begin{array}{l}\text { Evaluation by teacher and peer evaluation } \\
\text { Reflection and self-evaluation sessions facilitated by teachers } \\
\text { Exhibition of posters }\end{array}$ \\
\hline
\end{tabular}

\section{Conclusion}

We have seen that there is a major tendency both at country level, such as Denmark and worldwide, to extend the practice of interprofessional collaboration also in other areas, given the benefits from the medical field. Danish education is one of the systems that have understood and developed 
interprofessional education programs and it is today in full ascension on the formation of these competencies. In case of Romania, as we have seen, we are in the beginning, with timid attempts in the social and educational fields. In this situation, we wanted by this article to bring a theoretical addition and methodological proposal to the practice of developing the interprofessional collaboration skills in Romania.

Finally, the biggest argument in support of the interprofessional skills training programs development is simply outlined and punctuated by Vishwas Chavan (2012 p. 25): collaboration has a formidable power, a single man, can never acquire all the skills needed to solve all problems, so, you have to ask for help, "borrow" from the skills of others to manage situations and solve problems, and for this you need to be competent, have communication and interprofessional collaboration skills, otherwise you cannot be able to solve more and more complex tasks on your own, but fortunately interprofessional collaboration can be learned.

\section{References}

- Barr, H., Koppel, I., Reeves, S., Hammick, M. \& Freeth, D. (2005). Effective Interprofessional education: argument, assumption \& evidence. Oxford: Blackwell Publishing. https://doi.org/10.1002/9780470776445.

- Barr, H. (2015). Interprofessional Education. The Genesis of Global Movement. Retrieved from https://static.websitecreator.eu/var/m_f/fd/fd4/3631/153622Genesis_of_global_IPE_movement_2015.pdf?download.Barwell, J., Arnold, F., \& Berry, H. (2013). How interprofessional learning improves care. Nursing Time, $14-16$.

- Canadian Interprofessional Health Collaborative. (2010). A National Interprofessional Competency Framework University of British Columbia Vancouver. Retrieved from https://www.cihc.ca/files/CIHC_IPCompetencies_ Feb1210.pdf.

- Centre for the Advancement of Interprofessional Education. (1997). Interprofessional education - a definition. CAIPE Bulletin 13, 19.

- Chavan, V., (2012). Universal Principles of living inspired by real - life experiences. Bloomington: Author House.

- Drynan, D. (2013). Understanding and facilitating interprofessional education. A guide to incoroprating interprofessional experiences into the practice educational setting. Retrieved from http://physicaltherapy.med.ubc.ca/files/ 
2012/09/IPE-Guide-2nd-ed.-May-2012.pdf at 12.03.2018.

- EMS. (2017). 6 benefits of interprofessional collaboration. Retrieved from https://www.simulationiq.com/blog/content/6-benefits-interprofessionalcollaboration.

- Green, B., \& Johnson, C. (2015). Interprofessional collaboration in research, education, and clinical practice: working together for a better future. The Journal of Chiropractic Education, 1, 10. https://doi.org/10.7899/JCE-1436.

- Interprofessional Education Collaborative. (2016). Core Competencies for Interprofessional Collaborative Practice: Report of an Expert Panel. Washington, DC. Retrieved from https://ipecollaborative.org/uploads/IPECCore-Competencies.pdf.

- Ministry of Health and Prevention. (2018). Health Care in Denmark. Retrieved from http://tyskland.um.dk/de/ /media/Tyskland/German-site/Documents/ Reise\%20und\%20Aufenthalt/Health\%20Care\%20in\%20Denmark.pdf.

- Nielsen, A. Hamming, A. (2008). Interprofessional Education in Denmark. Esbjerg. Journal of Interprofessional Care. https://doi.org/10.1080/ 13561820701478229.

- World Economic Forum. (2015). The Future of Jobs Employment, Skills and Workforce Strategy for the Fourth Industrial Revolution. Retrieved from http://www3.weforum.org/ docs/WEF_Future_of_Jobs.pdf.

- World Health Organization (1988). Learning together to work together for health. Retrieved from http://apps.who.int/iris/handle/10665/37411.

The online version of this article can be found at: http://revped.ise.ro/category/2018-en/

\section{(cc) B $\mathrm{C}-\mathrm{NC}-\mathrm{EA}$}

This work is licensed under the Creative Commons Attribution-NonCommercial-ShareAlike 4.0 International License.

To view a copy of this license, visithttp://creativecommons.org/licenses/by-ncsa/4.0/ or send a letter to Creative Commons, $P O$ Box 1866, Mountain View, CA 94042, USA.
Versiunea online a acestui articol poate fi găsită la:http://revped.ise.ro/category/2018-ro/

\section{(cc) EY-Ne-sA}

Această lucrare este licen iată sub Creative Commons Attribution-NonCommercial-ShareAlike 4.0 International License.

Pentru a vedea o copie a acestei licen e, vizita $i$ http://creativecommons.org/licenses/by-nc-sa/4.0/ sau trimite i o scrisoare către Creative Commons, PO Box 1866, Mountain View, CA 94042, SUA. 